\title{
Assessing the subglacial lake coverage of Antarctica
}

\author{
Sebastian GOELLER, Daniel STEINHAGE, Malte THOMA, Klaus GROSFELD
}

Alfred Wegener Institute, Helmholtz Centre for Polar and Marine Research, Bremerhaven, Germany E-mail: sgoeller@awi.de

\begin{abstract}
Lakes beneath the Antarctic Ice Sheet are known to decrease traction at the ice base and therefore can have a great impact on ice dynamics. However, the total extent of Antarctic subglacial lakes is still unknown. We address this issue by combining modeling and remote-sensing strategies to predict potential lake locations using the general hydraulic potential equation. We are able to reproduce the majority of known lakes, as well as predict the existence of many new and so far undetected potential lakes. To validate our predictions, we analyzed ice-penetrating radar profiles from radio-echo sounding flights acquired over 1994-2013 in Dronning Maud Land, East Antarctica, and this led to the identification of 31 new subglacial lakes. Based on these findings, we estimate the total number of Antarctic subglacial lakes to be $\sim 1300$, a factor of three higher than the total number of lakes discovered to date. We estimate that only $\sim 30 \%$ of all Antarctic subglacial lakes and $\sim 65 \%$ of the total estimated lake-covered area have been discovered, and that lakes account for $\mathbf{0 . 6} \%$ of the Antarctic ice/bed interface.
\end{abstract}

KEYWORDS: Antarctic glaciology, radio-echo sounding, subglacial hydrology, subglacial lakes

\section{INTRODUCTION}

Antarctic subglacial lakes are discrete bodies of water that form between ice and bedrock at the base of the Antarctic Ice Sheet (Robinson, 1960; Robin and others, 1970). They can exist despite the very low surface temperatures of the Antarctic Ice Sheet because large areas of the ice-sheet base are at the pressure melting point, actively melting through the combined influence of the insulating ice cover, internal as well as basal strain heating and the geothermal heat flux into the base of the ice sheet (e.g. Pattyn, 2010). Meltwater then flows under the forces of gravity and the pressure of overburden ice (Shreve, 1972) and accumulates within subglacial topographic hollows forming subglacial lakes. Within the last five decades several hundred subglacial lakes have been discovered beneath the Antarctic Ice Sheet (inventory by Wright and Siegert, 2012). Observations also show that they are integrated into wide-ranging subglacial hydrological networks, where they accumulate basal meltwater from their upstream catchment areas and release it continuously or as floods towards other downstream located subglacial lakes and eventually to the ocean (e.g. Wingham and others, 2006; Fricker and others, 2007; Carter and others, 2009; Fricker and Scambos, 2009; Fricker and others, 2010). The long-term history of subglacial lakes is still unclear. Following Duxbury and others (2001) todays subglacial lakes might have already existed before the complete glaciation of Antarctica and survived the subsequent build-up of the Antarctic Ice Sheet. Pattyn (2004) supported this theory with ice model simulations while Siegert (2004) challenged this view and stated that the ice would have been grounded over the entire lake bed during the ice-sheet growth.

Subglacial lakes in Antarctica are mainly studied for three scientific reasons: First, subglacial lakes are one of the most unique and extreme habitats on Earth. They are isolated from the circulation of the atmosphere and subject to permanent darkness, low temperatures of -2 to $4^{\circ} \mathrm{C}$ and enormous pressure of 22-40 bar (e.g. Carter and others, 2007).
Metabolically active microorganisms were found in samples of accreted ice (water of the lake refrozen to its ice roof), proofing the existence of life despite the extreme conditions (e.g. Christner and others, 2014). Within the perspective of planetary science this indicates that life might exist under the surface of the Martian ice cap or the icy moons of Saturn and Jupiter (Wynn-Williams and Edwards, 2000; Duxbury and others, 2001; Siegert and others, 2001). Techniques developed for the exploration of Antarctic subglacial lakes (Siegert and others, 2007) therefore have applications to search for extra-terrestrial life as well.

Second, sediments existing at the base of subglacial lakes may contain high-resolution records of ice-sheet history (e.g. Siegert, 2000). Following Zotikov (1987) the steady flow of dirty ice across a subglacial lake combined with low melting rates at the ice/lake interface of $\sim 1 \mathrm{~mm} \mathrm{a}^{-1}$ results in a very low sedimentation rate. Since subglacial lakes may be millions of years old, sediment layers in the order of tens or hundreds of meters could have accumulated at the lake bottom. These sedimentary records could represent a climate archive containing proxies and biodata ageing back to 5-30 Ma BP. Current ice cores are only able to reconstruct ice sheet history for 740000 a (Augustin and others, 2004) whereby a possible maximum age of $\sim 1.5 \mathrm{Ma}$ has been estimated for Antarctic ice cores (Fischer and others, 2013).

The third reason is the most relevant one for this study: subglacial lakes are an important component of the widespread hydraulic system beneath the Antarctic Ice Sheet. They are known to interact with the overlying ice and considerably affect the ice dynamics (Stearns and others, 2008; Siegfried and others, 2014). The basal friction of the moving ice sheet reduces to zero at subglacial lake surfaces. This leads to a distinct local increase of the ice velocities (e.g. Kwok and others, 2000; Pattyn and others, 2004) and also has an impact on the adjacent and far-away ice flow (Thoma and others, 2012). The modeling of water circulation inside a subglacial lake reveals local melting and refreezing rates at the ice/water interface of the order of $1-10 \mathrm{~mm} \mathrm{a}^{-1}$ 
(Thoma and others, 2008, 2009, 2010, 2012). These thermodynamic processes at the lake-ice boundary alter the ice temperature by up to $10 \%$ and thereby modify the highly nonlinear ice viscosity (Thoma and others, 2012), which rules the ice creep behavior. In summary, it can be stated that subglacial lakes crucially affect the velocity and direction of the ice flow as well as the thermal regime of the ice sheet.

In this paper, we estimate the total number of Antarctic subglacial lakes and their coverage of the ice/bed interface beyond the already known lakes. Thus, we improve the understanding of coupling between the ice sheet and the bedrock and the influence of this coupling on the Antarctic Ice Sheet's dynamic. We use the observed topography of the Antarctic Ice Sheet and the underlying bedrock (Fretwell and others, 2013) to predict positions and extents of potential subglacial lakes (similar to Livingstone and others, 2013). This method is evaluated by comparing the predicted lakes with the latest inventory of Antarctic subglacial lakes (Wright and Siegert, 2012) and a selective interpretation of radar profiles from radio-echo sounding (RES) flight campaigns by the Alfred Wegener Institute (AWI). Subsequently, these findings are used to estimate the number and extent of Antarctic subglacial lakes yet to be discovered.

\section{METHODS}

\section{Predicting subglacial lakes}

The hydraulic potential $p$ (Shreve, 1972) at the base of an ice sheet is defined by basal water pressure $p_{\mathrm{w}}$ and bedrock elevation $B$

$$
p=g \rho_{\mathrm{w}} B+p_{\mathrm{w}}
$$

with water density $\rho_{\mathrm{w}}$ and gravitational acceleration $g$. The locally prevailing flow regime depends on the water pressure and the geological properties of the substrate at the lower ice surface in a complex manner (e.g. Clarke, 2005). There is a distinction between channelized and distributed flow regimes: channelized systems transport large volumes of water in discrete tunnels at high effective pressure (ice overburden pressure minus water pressure), which increases with increasing water flux (e.g. Roethlisberger, 1972; Nye, 1973). Distributed systems comprise water transport in systems of linked cavities (e.g. Lliboutry, 1968), flow through a water film between ice and bedrock (e.g. Weertman, 1972), flow incanals eroded into sediment (e.g. Walder and Fowler, 1994) and flow within groundwater and till (e.g. Alley and others, 1986). They transport basal meltwater at low effective pressure, which decreases with increasing water flux.

The gradients of the hydraulic potential (Eqn (1)) determine the flow direction of basal meltwater, which can accumulate in hollows of the hydraulic potential, forming subglacial lakes. These subglacial lakes belong to the distributed flow systems, where sparse borehole measurements show that the water pressure is very close to the overburden ice pressure (e.g. Kamb, 2001). Consequently, the approximation of assuming an effective pressure of zero allows to simplify the calculation of the hydraulic potential whenever the primary focus is on the investigation of distributed flow systems and larger timescales (e.g. Budd and Jenssen, 1987; Alley, 1996). In this case, the hydraulic potential at the base of grounded ice can be calculated using bedrock elevation $B$ and ice pressure $p_{\mathrm{i}}$ derived from ice thickness $H$ and ice density $\rho_{\mathrm{i}}$

$$
p=g\left(\rho_{\mathrm{w}} B+\rho_{\mathrm{i}} H\right) .
$$

The respective datasets for Antarctica are provided within the Bedmap2 dataset (Fretwell and others, 2013) and are resampled to a grid resolution of $5 \mathrm{~km}$.

Model results of Pattyn (2010) show that $\sim 55 \%$ of the Antarctic Ice Sheet base could be at its pressure melting point and produce meltwater while the rest of the ice sheet might be frozen to the bedrock. The underlying ice temperature calculation considers (besides advection and diffusion terms) several thermal influences: internal heating by ice deformation and the mean annual air temperature at the ice-sheet surface as well as the combined influence of the geothermal heat flux and frictional heat contributions at the ice/bed interface, resulting from ice sliding over the bed. In particular, these basal processes are assumed to have the major impact on the thermal balance of the ice sheet. The sliding of ice over bedrock is described by a number of theories (review by Fowler, 2010), which unfortunately cannot be approved by observations due to the inaccessibility of the Antarctic Ice Sheet's base. The available geothermal heat flux datasets (e.g. Shapiro and Ritzwoller, 2004; Maule and others, 2005) show large differences. Furthermore, estimates of the geothermal heat flux cannot be confirmed by direct measurements. Consequently, the implementation of the thermally relevant basal processes in ice modeling is still subject to large uncertainties. Hence, we assume that the whole Antarctic Ice Sheet base is at its pressure melting point and produces meltwater, possibly leading to an overprediction of subglacial lakes. To account for this, we validate the results using radar observations at a later stage.

In general, meltwater follows the gradient of the hydraulic potential (Eqn (1)) and pools within hollows of the hydraulic potential surface until they overspill and the water flow continues to regions further downstream. Under the assumption that the hydraulic system is acting on much smaller timescales than the ice dynamics, the hydraulic system can be regarded to be in a quasi-stationary equilibrium state. Accordingly, all hollows of the hydraulic potential are assumed to be filled to their maximum level forming subglacial lakes. In the following, the theoretical prediction of subglacial lakes in Antarctica is done by calculating the basal hydraulic potential (Eqn (2)) and filling all potential hollows to their maximum level.

\section{Comparison of predicted and known subglacial lakes}

So far, 379 lakes have been identified beneath the Antarctic Ice Sheet using satellite altimetry, airborne RES or seismic investigations. They are listed in an inventory compiled by Wright and Siegert (2012). For the following comparison, the listed geographic positions of the observed lakes are interpreted as the central lake positions, because an estimate of their outline only exists for seven lakes, while no length is given for 131 lakes. For all predicted lakes the outlines are determined and expanded by a buffer zone of $5 \mathrm{~km}$, which is thought to compensate the uncertainties originating from the $5 \mathrm{~km}$ grid resolution. A predicted subglacial lake is considered to successfully match an observed subglacial lake if 
the central position of the observed lake is situated inside the expanded outlines of the predicted lake.

\section{RES and matching of predictions with flight lines}

The technique of RES takes advantage of the ability of electromagnetic waves to travel comparatively freely through both air and ice. These waves are partially reflected at boundaries between materials with different dielectric properties and therefore different speeds of wave propagation. A pair of active transmit/receive radar antennas attached to an airborne (e.g. Oswald and Robin, 1973; Blankenship and others, 2001) or ground-based vehicle (e.g. Welch and Jacobel, 2003) can thus be used to detect reflections from the base or within an ice sheet. Airborne RES with a frequency of $60 \mathrm{MHz}$ is able to penetrate over $4000 \mathrm{~m}$ of cold ice (e.g. Robin and others, 1977) because the Antarctic ice with its low temperatures is relatively transparent to electromagnetic radiation at this frequency (Johari and Charette, 1975). The basal reflection strength depends predominantly upon the difference in dielectricity of the ice $(\varepsilon=3.2$; Bohleber and others, 2012) and the underlying material. Because the dielectric constant of water $(\varepsilon=81)$ is much higher than the one of bedrock ( $\varepsilon=4$ to 9 ) the ice/water interface causes a much stronger reflection. Additionally, the bedrock surface, which is rough compared with the smooth water surface of a subglacial lake, scatters the wave energy, decreasing its reflection strength further (Siegert, 2000). Consequently, subglacial lakes can be identified on RES records by specular or mirror-like reflections with an echo strength being 10-20 dB brighter than reflections from ice/bedrock interfaces. The depth of subglacial lakes cannot be determined by RES because the majority of the electromagnetic radiation is reflected at the lake surface. The transmitted part is quickly absorbed and therefore does not yield enough energy to be recorded at the ice-sheet surface.

Numerous AWI RES flight campaigns surveyed large parts of the Antarctic Ice Sheet during the summer seasons of the Southern Hemisphere. In this study, all RES flight lines between 1994 and 2013 (there were no campaigns in 1999/2000, 2006/07 and 2009/10) are taken into consideration for a comparison with the locations of the predicted subglacial lakes. For flight lines, which cross the outlines of a predicted lake, images of the associated radar profiles are processed for the segment matching the extent of the predicted lake expanded by $5 \mathrm{~km}$ at both sides. In a visual analysis of all 270 images the radar reflections at the ice-sheet base were checked for characteristic bright and flat basal lake surface radar reflections.

\section{RESULTS AND INTERPRETATION}

In the calculated basal hydraulic potential of the Antarctic Ice Sheet, 10183 hollows can be identified and filled, which are interpreted as potential or predicted subglacial lakes (Fig. 1). The majority of the lakes and particularly all larger lakes are clustered close to ice divides. There, the ice-sheet surface is relatively flat and the hydraulic potential is primarily influenced by the bedrock. Thus, troughs in the bedrock are also troughs in the hydraulic potential, allowing the basal meltwater to pool. Towards the ice-sheet margins the lake concentration decreases because of the higher prevailing ice-sheet surface gradients. Their influence on the basal

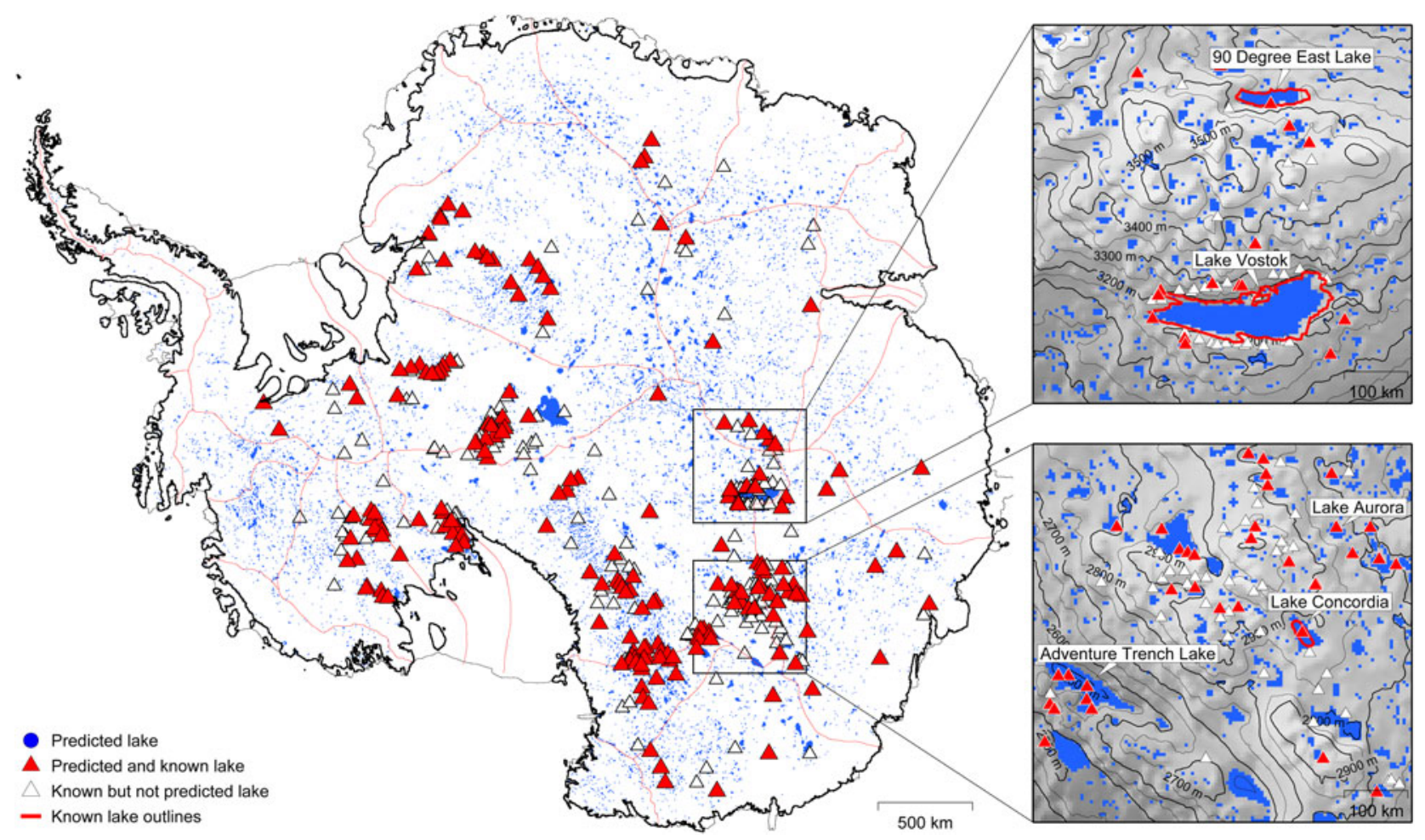

Fig. 1. Antarctic Ice Sheet with 10183 predicted subglacial lakes (blue) and locations of all 379 observed subglacial lakes (triangles, inventory by Wright and Siegert, 2012). 206 of them (red triangles) were successfully predicted. Map sections on the right show additionally the hydraulic potential (gray, contour lines) and known outlines of observed lakes (red lines) according to Filina and others (2008) and Studinger and others (2003) for two selected regions in central East Antarctica. Coast and grounding line (black) by NSIDC and ice divides (red) by AGAP. 
hydraulic potential is dominating the bedrock gradients by about one order of magnitude. As a consequence, hydraulic hollows and by association subglacial lakes occur only in comparatively deep bedrock depressions.

Furthermore, the local concentration of predicted lakes depends on the number of locally available RES flight lines, which were used to reconstruct the bedrock topography. Currently, the bedrock is well surveyed in most Antarctic regions (e.g. Dronning Maud Land or the Siple Coast) but, there are still areas (e.g. beneath the East Antarctic Ice Sheet) where it is reconstructed from a very sparse number of measurements (Fretwell and others, 2013). A higher resolution of the known bedrock elevation necessarily results in an increased number of hollows in the hydraulic potential and, thus, more predicted lakes. This additionally explains the spatially varying concentration of predicted lakes and is confirmed by the use of an earlier dataset for Antarctic bedrock elevation and ice thickness based on far less comprehensive observations (Albmap by Le Brocq and others, 2010) where only 2764 potential lakes are found.

In total, an area of $590900 \mathrm{~km}^{2}$ is found to be covered by surfaces of predicted Antarctic subglacial lakes (4.9\% of the area of Antarctic grounded ice). This is in agreement with estimates of Siegert (2000), who stated that $\approx 5 \%$ of the icesheet base might be occupied by subglacial lakes and modeling results of Livingstone and others (2013) who found a lake coverage of $3.7 \%$ based on the prediction of 12767 lakes with a similar method. The areal extents of the particular predicted lakes ranges from 25 to $16375 \mathrm{~km}^{2}$. Their majority (6829 lakes, $67 \%$ ) comprises surfaces of $25 \mathrm{~km}^{2}$ corresponding to a single grid cell at the applied grid resolution of $5 \mathrm{~km}$. The average lake size is $58 \mathrm{~km}^{2}$ and only 30 predicted lakes $(0.3 \%)$ have surfaces of $1000 \mathrm{~km}^{2}$ and beyond.

In comparison with the inventory of Antarctic subglacial lakes (Wright and Siegert, 2012), 206 out of 379 observed Antarctic subglacial lakes (54\%) are found to be correctly predicted (Fig. 1). All larger lakes like Lake Vostok, Lake $90^{\circ}$ East, Adventure Trench Lake, Lake Concordia and Lake Aurora were successfully predicted. Particularly for the known outlines of Lake Vostok, Lake $90^{\circ}$ East and Lake Concordia the congruence with the predicted lake extents is outstanding.

The outlines of the predicted lakes are found to be crossed by a RES flight line at 804 locations. Restricting the search results to areas where the radar penetrated the ice sheet and reached the bedrock, 270 flight lines crossing 263 predicted subglacial lakes are obtained. The visual analysis of the associated RES profiles yields the identification of potential subglacial lake surfaces in 40 flight lines crossing 33 predicted subglacial lakes (Fig. 2). Three of these flight lines cross known subglacial lakes: two Lake Vostok and one the Adventure Trench Lake (red triangles). As expected, the associated radar profiles show clearly recognizable lake surface reflections. The radar profiles of the remaining 36 flight lines show potential basal lake surfaces at the locations of 31 predicted and so far uncharted subglacial lakes (blue triangles in Fig. 2, list with positions in Appendix). In 230 of the analyzed radar profiles no typical basal water reflections are found (gray triangles).

As an example, three selected radar profiles in Dronning Maud Land of locations, where so far uncharted lakes are

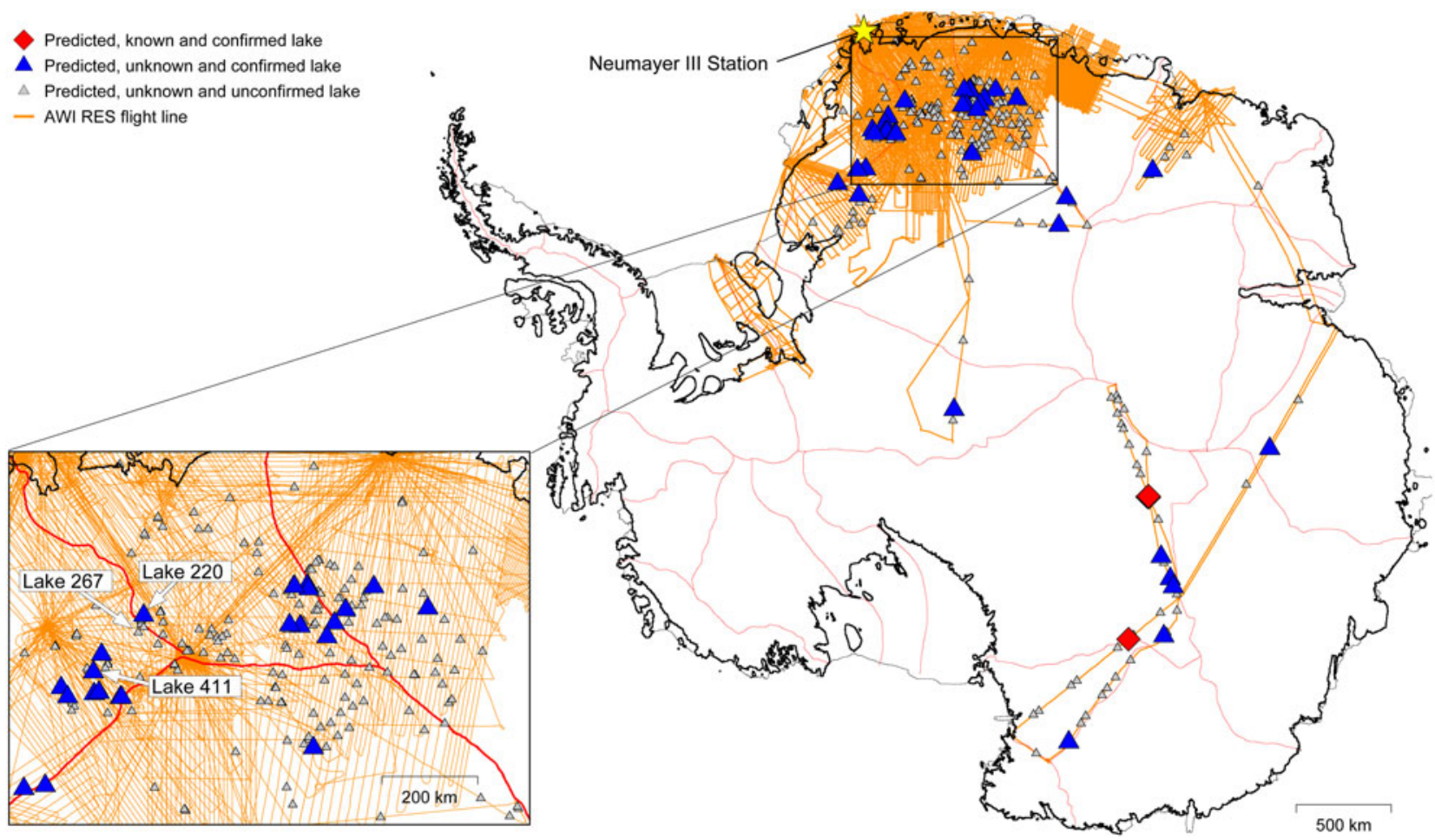

Fig. 2. All AWI RES flight lines (orange) in Antarctica from 1994 to 2013. Triangles mark locations where flight lines cross the outline of a predicted subglacial lake. Red diamonds indicate predicted and already known subglacial lakes (Lake Vostok and Adventure Trench Lake) ascertained by a cleary visible lake surface reflection in the associated radar profile. Gray triangles stand for predicted and so far uncharted subglacial lakes where no lake surface could be detected in the radar profiles. Predicted and so far uncharted subglacial lakes where a potential lake surface reflection is found in the radar profile are pointed out by blue triangles. For three selected predicted lakes (labeled in map section) the radar profile is shown in Figure 3. Coast and grounding line (black) by NSIDC and ice divides (red) by AGAP. 
predicted, are shown in Figure 3. The radar profiles show the surface and the internal stratigraphy of the ice sheet as well as the underlying bedrock. The extents of the predicted lakes are indicated and show a very good correlation with the extents of the hollows in the bedrock topography. For these selected profiles, the hydraulic potential is mainly governed by the bedrock topography because the ice-sheet surface is flat compared with variations in the bedrock elevation. Assuming the bedrock hollows filled with water to their maximum level, exactly the predicted lake extents are identified (see marks in Fig. 3). Although the predictions are based on datasets where bedrock and ice-sheet geometry were interpolated onto grids with spatial resolutions of $5 \mathrm{~km}$, the predictions and observations show a remarkably precise congruence. This comfirms the validity of the applied algorithm to identify and fill hollows in the hydraulic potential.

The radar profiles in Figures $3 \mathrm{a}$ and $\mathrm{b}$ additionally show bright and flat reflections at the bottom of the bedrock hollows. These reflectors are interpreted as the surfaces of subglacial lakes, which have lengths between 3 and $5 \mathrm{~km}$. Their existence reveals that the ice sheet is locally at its pressure melting point, producing meltwater. However, the observed bedrock trough is not filled to its maximum level. This might have two different reasons: The identified lakes might have a narrow outlet in the direction orthogonal to the orientation of the flight line, which is not incorporated in the topography dataset due to the density of locally available measured data and the applied interpolation method (Fretwell and others, 2013). Secondly, they also might be active subglacial lakes, which recently drained and therefore are not filled to their maximum possible extent (Smith and others, 2009).

In Figure 3c the basal radar reflections around the bedrock trough show no evidence for the occurence of accumulated water despite the prediction of a subglacial lake at this position. A possible explanation could again be an existing outlet in the direction orthogonal to the orientation of the flight line, which is not incorporated in the used gridded dataset. Available meltwater would then not be able to accumulate but would flow further down the hydraulic potential. Another possibility for the observed absence of a predicted lake despite the existence of an appropriate hydraulic hollow could be found in the local thermal regime of the ice sheet. The ice-sheet base is potentially not at its pressure melting point at this location. In this particular case, the ice would be frozen to the bedrock and no meltwater would be produced. Consequently, even hydraulic hollows would stay dry.

\section{DISCUSSION}

The majority of the known subglacial lakes are correctly predicted by the introduced method. In comparison, Livingstone and others (2013) reproduced $61 \%$ of the known lakes with a similar approach but using buffer zones equivalent to the known lake sizes. These prediction success rates are astonishing since the lake surface reflectors are incorporated in the bedrock topography and ice thickness data in the used Bedmap2 dataset (Fretwell and others, 2013). For this reason, no hollows in the hydraulic potential should occur at the locations of existing subglacial lakes. Indeed, this is the case for lakes, which are filled with water up to their hydraulic lip and might account for some of the observed subglacial lakes, which could not have been theoretically predicted. A high percentage of the known subglacial lakes in the current inventory, however, were detected by icesheet surface elevation changes and therefore are considered active subglacial lakes (e.g. Smith and others, 2009). These kind of lakes are periodically filling and draining and might be at an intermediate lake level at the time of the respective RES bedrock elevation and ice thickness survey. The difference between the actual lake surface and the highest possible water level would then be interpreted as hydraulic hollow and consequently as a predicted lake. Another
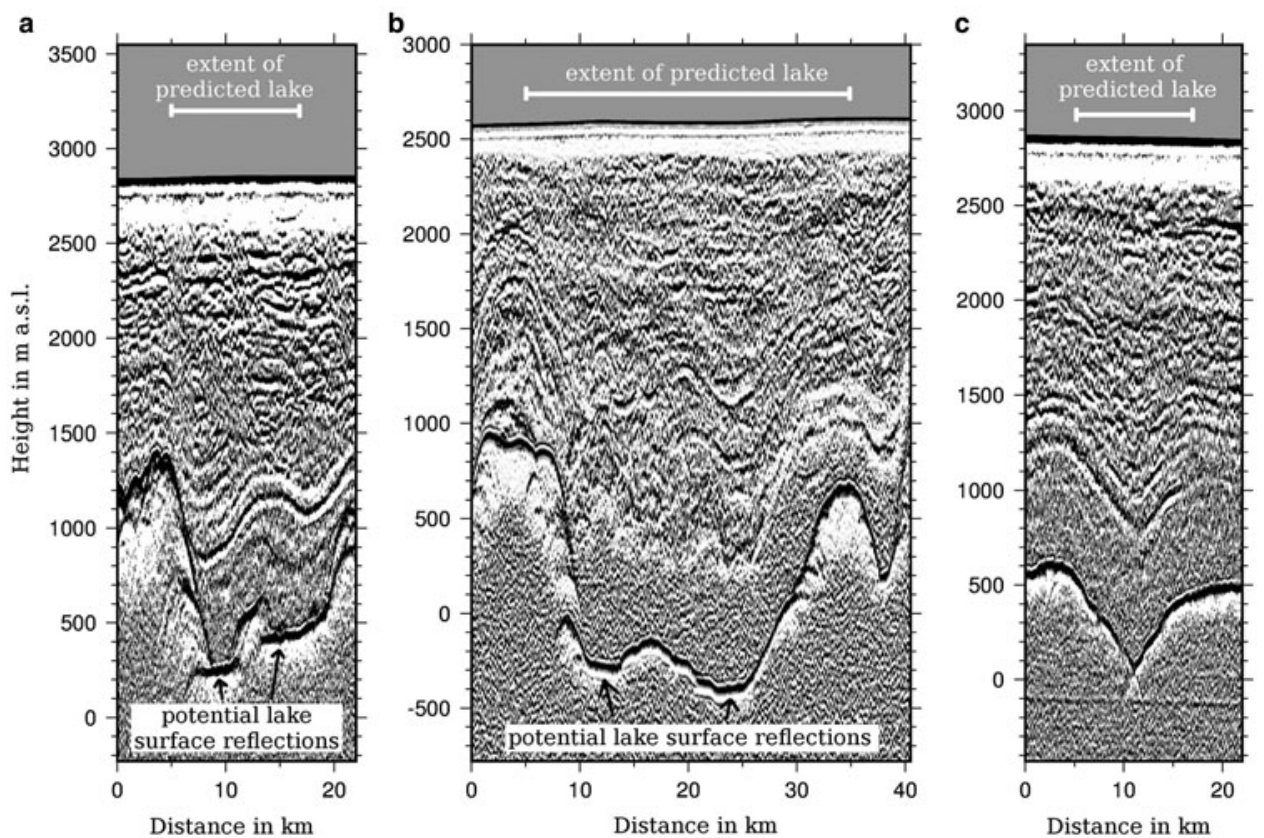

Fig. 3. Selected radar profiles of AWI RES flight lines crossing predicted and so far uncharted subglacial lakes (Fig. 2). All three profiles show a hollow in the bedrock topography in good agreement with the predicted maximum possible lake extent. Profile (a) and (b) show strong and flat lake-like radar reflections at the bottom of the bedrock troughs. The basal reflections in profile (c) show no indications for the existence of accumulated basal water. 
reason for the successful identification of known subglacial lakes, despite the incorporation of the lake surface reflector in the topography datasets, could be justified by the processing of the topography data. Although the originally alongtrack resolution of RES records is comparatively high, the interpolation onto a grid size in the order of kilometers could smooth out the elevation of a narrow lake outlet. In this manner, the rim of an existing and water-filled basal hydraulic hollow would be artificially raised, again leading to the detection of a hydraulic hollow and therefore to the prediction of a subglacial lake at this spot (discussed by Livingstone and others, 2013).

Interpolation artefacts, originating from bedrock geometry processing and creating hydraulic hollows, can also be a reason for the overprediction of subglacial lakes and explain the large discrepancy between 10183 predicted and so far only 379 observed subglacial lakes in Antarctica. Another argument to explain this discrepancy in the number of lakes can be found in the surface area distribution of the predicted lakes. The majority of the predicted lakes have surface areas of $25 \mathrm{~km}^{2}$, corresponding to an idealized circular lake diameter of $5.6 \mathrm{~km}$. Buried beneath ice thicknesses of up to $4 \mathrm{~km}$, such small lakes have no impact on the appearance of the ice surface. The ice column above these lakes is mainly supported by the lateral ice sheet and not in floating equilibrium (e.g. Wright and Siegert, 2011). In contrast, flat ice surfaces are very characteristic above lakes with the size of several times the ice thickness (e.g. Bell and others, 2007; Smith and others, 2009). The inventory of Antarctic subglacial lakes by Wright and Siegert (2012) mostly includes lakes, which were identified by icesheet surface features observed by satellite laser altimetry. Consequently, the current inventory might be lacking a large amount of these so far undiscovered smaller lakes. This hypothesis will be investigated below, where the existence of uncharted predicted lakes is verified on the basis of AWI RES profiles.

Out of 263 predicted lakes crossed by AWI flight lines, 33 lakes could be identified by analyzing the associated RES profiles. Beside two already known subglacial lakes, 31 new subglacial lakes are found. In general, the interpretation of radar profiles does not always provide unambiguous results and in some cases additional investigations (e.g. seismic explorations) might be necessary to achieve clarity. Therefore, we estimate the uncertainty of our visual analysis with respect to the number of identified subglacial lakes by quoting an error margin in the amount of eight lakes. In this way, a corresponding prediction success rate of $13 \pm$ $3 \%$ is obtained. This rate is gained almost exclusively by the evaluation of AWI RES flights covering Dronning Maud Land, the region southeast of the Neumayer III Station (Fig. 2). Despite the very good coverage by remote sensing campaigns, only a very few subglacial lakes have been found in this region so far (Fig. 1, Wright and Siegert, 2012). One reason might be the bedrock topography in this area, which is largely flat compared with other Antarctic regions like, e.g. the Gamburtsev Mountains (Fretwell and others, 2013). Another explanation might be the local thermal regime at the ice base. According to model results from Pattyn (2010), the ice-sheet base for some parts of Dronning Maud Land could not be at its pressure melting point. Consequently, no local meltwater would be available to form subglacial lakes. This study is based on the simplified assumption that the Antarctic Ice Sheet is wholly warm- based, which might lead to an overprediction of subglacial lakes in this particular region. However, on a drill site in Dronning Maud Land, subglacial water was found, entering the borehole at the final depth of $2774 \mathrm{~m}$ (Oerter and others, 2009), despite ice modeling predicting a dry bed (Pattyn, 2010). In general, the prediction success rate of $13 \pm 3 \%$ should be considered as a lower boundary for estimates concerning the entire Antarctic Ice Sheet for the above reasons. Furthermore, the predictive power might be increased in future studies by combining the applied approach with other methods regarding the automated analysis of bedrock roughness and basal radar reflection strength along flight lines.

Ensuing from the results of the radar-based validation of predicted subglacial lakes, mostly in Dronning Maud Land, the overall number and surface area of Antarctic subglacial lakes can be estimated. In total, 10183 subglacial lakes with an overall surface of $590900 \mathrm{~km}^{2}$ are predicted. Corresponding to the obtained prediction success rate of $13 \pm 3 \%, 1300 \pm 300$ subglacial lakes are estimated to exist beneath the grounded Antarctic Ice Sheet. Compared with the current inventory (Wright and Siegert, 2012), which lists 379 subglacial lakes, there are still $921 \pm 300$ lakes to be discovered, indicating that only $\sim 30 \%$ of all existing lakes are known so far. Due to the explanations above, the applied success rate and, by implication, the obtained number of undiscovered lakes should be considered as a lower boundary of the estimate. Applying the obtained prediction success rate on the overall predicted subglacial lake surface, the area of $\sim 77000 \pm 18000 \mathrm{~km}^{2} \quad(0.6 \pm 0.2 \%)$ beneath the Antarctic Ice Sheet is estimated to be covered by subglacial lakes. Wright and Siegert (2011) assessed the total surface of known subglacial lakes to be $\sim 50000 \mathrm{~km}^{2}$ using the circular approximation for lakes crossed by just a single survey line. This means that $\sim 65 \%$ of the subglacial lake surfaces are already charted while only $\sim 30 \%$ of the estimated number of subglacial lakes is known so far. Consequently, the majority of the undiscovered subglacial lakes is estimated to be comparatively small with an average surface extent of $\sim 29 \mathrm{~km}^{2}$. This finding is very reasonable since all larger subglacial lakes are considered to have already been discovered by satellite altimetry.

\section{CONCLUSION}

Subglacial lakes are an important component of the hydraulic system beneath the Antarctic Ice Sheet and have a large impact on ice dynamics. We assess their total coverage of the ice base by using both modeling and remote-sensing approaches. Based on the calculated basal hydraulic potential at the base of the Antarctic Ice Sheet locations and extents of potential subglacial lakes are predicted (Livingstone and others, 2013). The validity of this method is approved by the successful theoretical prediction of 206 observed subglacial lakes in the current inventory (379 lakes; Wright and Siegert, 2012). Subsequently, the specific analysis of RES profiles at the locations of predicted lakes is used as a tool to estimate the value of the applied method regarding the prediction of so far uncharted subglacial lakes. A comparison of RES flight lines from 1994 to 2013 of the Alfred Wegener Institute and predicted lake outlines yields 263 matches, where in 33 of these radar profiles basal water reflections are identified. Two of them are associated with already known subglacial lake surfaces and 31 reveal the locations 
Table 1. Summary of the results for the prediction of subglacial lakes and their inventory- and radar-based validation

\begin{tabular}{ccccc}
\hline $\begin{array}{c}\text { Lake } \\
\text { predicted }\end{array}$ & $\begin{array}{c}\text { Lake in } \\
\text { inventory }\end{array}$ & $\begin{array}{c}\text { Lake crossed } \\
\text { by flight line }\end{array}$ & $\begin{array}{c}\text { Lake identified } \\
\text { by radar }\end{array}$ & Count \\
\hline$\checkmark$ & & & & 10183 \\
& $\checkmark$ & & & 379 \\
$\checkmark$ & $\checkmark$ & & & 206 \\
$\checkmark$ & $\checkmark$ & $\checkmark$ & $\checkmark$ & 2 \\
$\checkmark$ & $\checkmark$ & $\checkmark$ & & 263 \\
$\checkmark$ & & $\checkmark$ & $\checkmark$ & 31 \\
$\checkmark$ & & $\checkmark$ & & \\
\hline
\end{tabular}

of so far uncharted subglacial lakes (Table 1, list in Appendix). Based on the obtained prediction success rate, the total number of Antarctic subglacial lakes can be estimated to $1300 \pm 300$. The estimated surface area of these lakes adds up to $77000 \pm 18000 \mathrm{~km}^{2}$, corresponding to $\sim 0.6 \pm 0.2 \%$ of the Antarctic ice/bed interface. Respective to assessments of Wright and Siegert (2011) it can be estimated that $30 \%$ of all Antarctic subglacial lakes and $65 \%$ of the total estimated lake-covered area are discovered by now. Similar analyses of airborne or ground-based campaigns from other institutes and in other Antarctic regions could validate and improve the above assessments of the subglacial lake coverage, which is an important contribution towards a better understanding and a more realistic modeling of ice dynamics with respect to the future evolution under the influence of a warming climate.

\section{ACKNOWLEDGEMENTS}

This work was funded by the Helmholtz Climate Initiative REKLIM (Regional Climate Change), a joint research project of the Helmholtz Association of German research centres (HGF).

\section{REFERENCES}

Alley RB (1996) Towards a hydrological model for computerized ice-sheet simulations. Hydrol. Process., 10(4), 649-660 (doi: 10.1002/(SICI)1099-1085(199604)10:4<649::AID-HYP397>3.0. $\mathrm{CO} ; 2-1)$

Alley RB, Blankenship D, Bentley C and Rooney ST (1986) Deformation of till beneath ice stream B, West Antarctica. Nature, 322, 57-59 (doi: 10.1038/322057a0)

Augustin L and 9 others and others (2004) Eight glacial cycles from an Antarctic ice core. Nature, 429(6992), 623-628 (doi: 10.1038/nature02599)

Bell RE, Studinger M, Shuman CA, Fahnestock MA and Joughin I (2007) Large subglacial lakes in East Antarctica at the onset of fast-flowing ice streams. Nature, 445, 904-907 (doi: 10.1038/ nature05554)

Blankenship DD and 9 others (2001) Geologic controls on the initiation of rapid basal motion for West Antarctic ice streams: a geophysical perspective including new airborne radar sounding and laser altimetry results. West Antarct. Ice Sheet: Behavior Environ., 105-121 (doi: 10.1029/AR077p0105)

Bohleber P, Wagner N and Eisen O (2012) Permittivity of ice at radio frequencies: part II. Artificial and natural polycrystalline ice. Cold Reg. Sci. Technol., 83, 13-19 (doi: 10.1016/j.coldregions. 2012.05.010)

Budd WF and Jenssen D (1987) Numerical modelling of the largescale basal water flux under the West Antarctic Ice Sheet. In Veen CJ and Oerlemans J eds. Dynamics of the West Antarctic
Ice Sheet, Springer, Netherlands, vol. 4 of Glaciology and Quaternary Geology, 293-320

Carter SP and 5 others (2007) Radar-based subglacial lake classification in Antarctica. Geochem. Geophys. Geosyst., 8(3) (doi: 10.1029/2006GC001408)

Carter SP and 5 others (2009) Dynamic distributed drainage implied by the flow evolution of the 1996-1998 Adventure Trench subglacial lake discharge. Earth Planet. Sci. Lett., 283(1), 24-37 (doi: 10.1016/j.epsl.2009.03.019)

Christner BC and 10 others and the WISSARD Science Team (2014) A microbial ecosystem beneath the West Antarctic ice sheet. Nature, 512, 310-313 (doi: 10.1038/nature13667)

Clarke GKC (2005) Subglacial processes. Ann. Rev. Earth Planet. Sci., 33, 247-276 (doi: 10.1146/annurev.earth.33.092203.122621)

Duxbury NS, Zotikov IA, Nealson KH, Romanovsky VE and Carsey FD (2001) A numerical model for an alternative origin of Lake Vostok and its exobiological implications for Mars. J. Geophys. Res., 106(E1), 1453-1462 (doi: 10.1029/2000J E001254)

Filina IY and 5 others (2008) New 3D bathymetry and sediment distribution in Lake Vostok: implication for pre-glacial origin and numerical modeling of the internal processes within the lake. Earth Planet. Sci. Lett., 276(1), 106-114 (doi: 10.1016/j.epsl. 2008.09.012)

Fischer $\mathrm{H}$ and 9 others (2013) Where to find 1.5 million yr old ice for the IPICS "Oldest Ice" ice core. Clim. Past Discuss., 9(3), 27712815 (doi: 10.5194/cpd-9-2771-2013)

Fowler AC (2010) Weertman, Lliboutry and the development of sliding theory. J. Glaciol., 56(200), 965-972 (doi: 10.3189/ 002214311796406112)

Fretwell P and 59 others (2013) Bedmap2: improved ice bed, surface and thickness datasets for Antarctica. Cryosphere, 7(1), 375-393 (doi: 10.5194/tc-7-375-2013)

Fricker HA and Scambos T (2009) Connected subglacial lake activity on lower Mercer and Whillans Ice Streams, West Antarctica, 2003-2008. J. Glaciol., 55(190), 303-315 (doi: 10.3189/ 002214309788608813)

Fricker HA, Scambos T, Bindschadler R and Padman L (2007) An active subglacial water system in west Antarctica mapped from space. Science, 315(5818), 1544-1548 (doi: 10.1126/ science.1136897)

Fricker HA and 5 others (2010) Synthesizing multiple remotesensing techniques for subglacial hydrologic mapping: application to a lake system beneath MacAyeal Ice Stream, West Antarctica. J. Glaciol., 56(196), 187-199 (doi: 10.3189/0022143 10791968557)

Johari GP and Charette PA (1975) The permittivity and attenuation in polycrystalline and single-crystal ice th at 35 and $60 \mathrm{MHz}$. J. Glaciol., 14(71), 293-303

Kamb B (2001) Basal zone of the West Antarctic ice streams and its role in lubrication of their rapid motion. Antarct. Res. Ser., 77, 157-199 (doi: 10.1029/AR077p0157)

Kwok R, Siegert MJ and Carsey FD (2000) Ice motion over Lake Vostok, Antarctica: constraints on inferences regarding the accreted ice. J. Glaciol., 46(155), 689-694 (doi: 10.3189/ 172756500781832710)

Le Brocq AM, Payne AJ and Vieli A (2010) An improved Antarctic dataset for high resolution numerical ice sheet models (ALBMAP v1). Earth Syst. Sci. Data, 2(2), 247-260 (doi: 10.5194/essdd-3-195-2010)

Livingstone SJ, Clark CD, Woodward J and Kingslake J (2013) Potential subglacial lake locations and meltwater drainage pathways beneath the Antarctic and Greenland ice sheets. Cryosphere, 7(6), 1721-1740 (doi: 10.5194/tc-7-1721-2013)

Lliboutry L (1968) General theory of subglacial cavitation and sliding of temperate glaciers. J. Glaciol., 7, 21-58

Fox Maule C, Purucker ME, Olsen N and Mosegaard K (2005) Heat flux anomalies in Antarctica revealed by satellite magnetic data. Science, 309, 464-467 (doi: 10.1126/science.1106888)

Nye JF (1973) Water at the bed of a glacier. IASH Publ. 95 (Symposium at Cambridge 1969 - Hydrology of Glaciers), 477-489 
Oerter H, Drücker C, Kipfstuhl S and Wilhelms F (2009) Kohnen station the drilling camp for the EPICA deep ice core in Dronning Maud Land. Polarforschung, 78(1/2), 1-23

Oswald GKA and de G and Robin Q (1973) Lakes beneath the Antarctic ice sheet. Nature, 245, 251-254 (doi: 10.1038/ 245251a0)

Pattyn F (2004) Comment on the comment by MJ Siegert on "A numerical model for an alternative origin of Lake Vostok and its exobiological implications for Mars" by NS Duxbury and others. J. Geophys. Res.: Planets (1991-2012), 109(E11) (doi: 10.1029/2004JE002329)

Pattyn F (2010) Antarctic subglacial conditions inferred from a hybrid ice sheet/ice stream model. Earth Planet. Sci. Lett., 295 (3-4), 451-461 (doi: 10.1016/j.epsl.2010.04.025)

Pattyn F, de Smedt B and Souchez R (2004) Influence of subglacial Vostok lake on the regional ice dynamics of the Antarctic Ice Sheet: a model study. J. Glaciol., 50(171), 583-589 (doi: 10.3189/172756504781829765)

Robin G, de Q, Swithinbank CWM and Smith BME (1970) Radio echo exploration of the Antarctic ice sheet. Int. Assoc. Sci. Hydrol. Pub., 86, 97-115

Robin G, de Q, Drewry DJ and Meldrum DT (1977) International studies of ice sheet and bedrock. Philos. Trans. R. Soc. London B Biol. Sci., 279(963), 185-196 (doi: 10.1098/rstb.1977.0081)

Robinson RV (1960) Experiment in visual orientation during flights in the Antarctic. Int. Bull. Soviet Antarct. Exped., 18, 28-29

Roethlisberger H (1972). Water pressure in intra- and subglacial channels. J. Glaciol., 11(62), 177-203

Shapiro NM and Ritzwoller MH (2004) Inferring surface heat flux distributions guided by a global seismic model: particular application to Antarctica. Earth Planet. Sci. Lett., 223(1-2), 213-224 (doi: 10.1016/j.epsl.2004.04.011)

Shreve RL (1972) Movement of water in glaciers. J. Glaciol., 11(62), 205-214

Siegert MJ (2000) Antarctic subglacial lakes. Earth-Sci. Rev., 50(1), 29-50 (doi: 10.1016/S0012-8252(99)00068-9)

Siegert MJ (2004) Comment on "A numerical model for an alternative origin of Lake Vostok and its exobiological implications for Mars" by NS Duxbury and others. J. Geophys. Res., 109, E02007 (doi: 10.1029/2003JE002176)

Siegert MJ and 6 others (2001) Physical, chemical and biological processes in Lake Vostok and other Antarctic subglacial lakes. Nature, 414(6864), 603-609 (doi: 10.1038/414603a)

Siegert MJ and 9 others and others (2007) Exploration of Ellsworth Subglacial Lake: a concept paper on the deGoeller and others: Assessing the subglacial lake coverage of Antarctica development, organisation and execution of an experiment to explore, measure and sample the environment of a West Antarctic subglacial lake. Rev. Environ. Sci. Bio/Technol., 6(1-3), 161-179 (doi: 10.1007/s11157-006-9109-9)

Siegfried MR, Fricker HA, Roberts M, Scambos TA and Tulaczyk S (2014) A decade of West Antarctic subglacial lake interactions from combined ICESat and CryoSat-2 altimetry. Geophys. Res. Lett., 41(3), 891-898 (doi: 10.1002/2013GL058616)

Smith BE, Fricker HA, Joughin IR and Tulaczyk S (2009) An inventory of active subglacial lakes in Antarctica detected by ICES at (2003-2008). J. Glaciol., 55(192), 573-595 (doi: 10.3189/ 002214309789470879)

Stearns LA, Smith BE and Hamilton GS (2008) Increased flow speed on a large East Antarctic outlet glacier caused by subglacial floods. Nat. Geosci., 1, 827-831 (doi: 10.1038/ ngeo356)
Studinger M and 9 others and others (2003) Ice cover, landscape setting, and geological framework of Lake Vostok, East Antarctica. Earth Planet. Sci. Lett., 205(3), 195-210 (doi: 10.1016/S0012-821X(02)01041-5)

Thoma M, Grosfeld K and Mayer C (2008) Modelling accreted ice in subglacial Lake Vostok, Antarctica. Geophys. Res. Lett., 35(11) (doi: 10.1029/2008GL033607)

Thoma M, Grosfeld K, Filina I and Mayer C (2009) Modelling flow and accreted ice in subglacial Lake Concordia, Antarctica. Earth Planet. Sci. Lett., 286(1), 278-284 (doi: 10.1016/j. epsl.2009.06.037)

Thoma M, Grosfeld K, Mayer C and Pattyn F (2010) Interaction between ice sheet dynamics and subglacial lake circulation: a coupled modelling approach. Cryosphere, 4(1), 1-12 (doi: 10.5194/tc-4-1-2010)

Thoma M, Grosfeld K, Mayer C and Pattyn F (2012) Ice-flow sensitivity to boundary processes: a coupled model study in the Vostok Subglacial Lake area, Antarctica. Ann. Glaciol., 53(60), 173-180 (doi: 10.3189/2012AoG60A009)

Walder JS and Fowler A (1994) Channelized subglacial drainage over a deformable bed. J. Glaciol., 40(134), 3-15

Weertman J (1972) General theory of water flow at the base of a glacier or ice sheet. Rev. Geophys. Space Phys., 10, 287-333 (doi: 10.1029/RG010i001p00287)

Welch BC and Jacobel RW (2003) Analysis of deep-penetrating radar surveys of West Antarctica, US-ITASE 2001. Geophys. Res. Lett., 30(8) (doi: 10.1029/2003GL017210)

Wingham DJ, Siegert MJ, Shepherd A and Muir AS (2006) Rapid discharge connects Antarctic subglacial lakes. Nature, 440(C6), 1033-1036 (doi: 10.1038/nature04660)

Wright A and Siegert MJ (2011) The identification and physiographical setting of Antarctic subglacial lakes: an update based on recent discoveries. In Siegert MJ and Kennicutt MC eds. Subglacial ntarctic aquatic environments, geophysical monograph series, Vol. 192, AGU, Washington, DC, 9-26 (doi: 10.1029/2010GM000933)

Wright A and Siegert MJ (2012) A fourth inventory of Antarctic subglacial lakes. Antarct. Sci., 24(6), 659-664 (doi: 10.1017/ S095410201200048X)

Wynn-Williams DD and Edwards HGM (2000) Antarctic ecosystems as models for extraterrestrial surface habitats. Planet. Space Sci., 48(11), 1065-1075 (doi: 10.1016/S0032-0633(00)00080-5)

Zotikov IA (1987) The thermophysics of glaciers, Reidel, Dordrecht

\section{APPENDIX}

Table 2 shows a list of 31 theoretically predicted and so far uncharted subglacial lakes in Antarctica where lake-like basal radar reflections were identified in the corresponding RES profiles. The result is based on the visual interpretation of 270 RES flight lines from flight campaigns of the Alfred Wegener Institute between 1994 and 2013 where the flight lines cross the contours of the predicted lakes. The tally for predicted lakes in Table 2 follows the inventory of all 10 183 predicted lakes, whereby some predicted lake locations are crossed by more than one flight line (e.g. lake 152). The given position is corresponding to the central shot number in the specified shot number range. As an additional information, the first two digits in the flight number describe the year of the respective flight campaign. 
Table 2. Predicted lake locations where lake-like basal radar reflections were identified in RES profiles from the Alfred Wegener Institute

\begin{tabular}{|c|c|c|c|c|}
\hline Tally & Longitude & Latitude & Flight line & Shot numbers \\
\hline 152 & $8.11^{\circ} \mathrm{E}$ & $73.46^{\circ} \mathrm{S}$ & 022119 & 6040-6144 \\
\hline 152 & $8.10^{\circ} \mathrm{E}$ & $73.47^{\circ} \mathrm{S}$ & 042016 & $11177-11334$ \\
\hline 152 & $8.23^{\circ} \mathrm{E}$ & $73.53^{\circ} \mathrm{S}$ & 042021 & 2830-2860 \\
\hline 154 & $12.43^{\circ} \mathrm{E}$ & $73.27^{\circ} \mathrm{S}$ & 042010 & 15-223 \\
\hline 155 & $7.25^{\circ} \mathrm{E}$ & $73.53^{\circ} \mathrm{S}$ & 042021 & 1975-1993 \\
\hline 201 & $10.91^{\circ} \mathrm{E}$ & $73.81^{\circ} \mathrm{S}$ & 082029 & $39230-39419$ \\
\hline 210 & $16.21^{\circ} \mathrm{E}$ & $73.41^{\circ} \mathrm{S}$ & 042032 & 7282-7304 \\
\hline 220 & $2.90^{\circ} \mathrm{W}$ & $74.18^{\circ} \mathrm{S}$ & 032003 & $11190-11222$ \\
\hline 234 & $8.01^{\circ} \mathrm{E}$ & $74.25^{\circ} \mathrm{S}$ & 042016 & $12929-13284$ \\
\hline 243 & $10.31^{\circ} \mathrm{E}$ & $74.09^{\circ} \mathrm{S}$ & 082029 & 9939-10 004 \\
\hline 246 & $7.27^{\circ} \mathrm{E}$ & $74.25^{\circ} \mathrm{S}$ & 022027 & $14561-14568$ \\
\hline 284 & $9.98^{\circ} \mathrm{E}$ & $74.37^{\circ} \mathrm{S}$ & 042015 & 6288-6314 \\
\hline 332 & $6.09^{\circ} \mathrm{W}$ & $74.85^{\circ} \mathrm{S}$ & 032021 & $12125-12364$ \\
\hline 411 & $6.82^{\circ} \mathrm{W}$ & $75.16^{\circ} \mathrm{S}$ & 982406 & 253-262 \\
\hline 457 & $9.37^{\circ} \mathrm{W}$ & $75.37^{\circ} \mathrm{S}$ & 052012 & $25012-25273$ \\
\hline 474 & $6.97^{\circ} \mathrm{W}$ & $75.58^{\circ} \mathrm{S}$ & 052010 & 4758-4887 \\
\hline 474 & $6.57^{\circ} \mathrm{W}$ & $75.56^{\circ} \mathrm{S}$ & 052109 & $2732-2780$ \\
\hline 474 & $6.61^{\circ} \mathrm{W}$ & $75.56^{\circ} \mathrm{S}$ & 982407 & 2263-2327 \\
\hline 489 & $9.00^{\circ} \mathrm{W}$ & $75.56^{\circ} \mathrm{S}$ & 052012 & $24403-24622$ \\
\hline 499 & $5.01^{\circ} \mathrm{W}$ & $75.70^{\circ} \mathrm{S}$ & 052107 & 2743-2837 \\
\hline 499 & $4.90^{\circ} \mathrm{W}$ & $75.70^{\circ} \mathrm{S}$ & 982102 & 5257-5337 \\
\hline 662 & $10.45^{\circ} \mathrm{E}$ & $76.49^{\circ} \mathrm{S}$ & 082029 & $15838-31083$ \\
\hline 799 & $12.07^{\circ} \mathrm{W}$ & $77.14^{\circ} \mathrm{S}$ & 952306 & 2315-2814 \\
\hline 816 & $13.90^{\circ} \mathrm{W}$ & $77.11^{\circ} \mathrm{S}$ & 952309 & 4858-4870 \\
\hline 831 & $41.93^{\circ} \mathrm{E}$ & $73.26^{\circ} \mathrm{S}$ & 062017 & $19077-19102$ \\
\hline 958 & $18.89^{\circ} \mathrm{W}$ & $77.48^{\circ} \mathrm{S}$ & 952409 & 8645-8653 \\
\hline 1100 & $15.00^{\circ} \mathrm{W}$ & $78.32^{\circ} \mathrm{S}$ & 952210 & 2839-3039 \\
\hline 1138 & $32.21^{\circ} \mathrm{E}$ & $76.81^{\circ} \mathrm{S}$ & 032141 & 2796-2819 \\
\hline 1480 & $34.14^{\circ} \mathrm{E}$ & $78.11^{\circ} \mathrm{S}$ & 032139 & $6073-6075$ \\
\hline 3999 & $60.29^{\circ} \mathrm{E}$ & $88.16^{\circ} \mathrm{S}$ & 112120 & $6641-7283$ \\
\hline 5054 & $93.34^{\circ} \mathrm{E}$ & $73.13^{\circ} \mathrm{S}$ & 082121 & $12119-12134$ \\
\hline 7379 & $118.12^{\circ} \mathrm{E}$ & $76.83^{\circ} \mathrm{S}$ & 082120 & 4247-4256 \\
\hline 7833 & $121.09^{\circ} \mathrm{E}$ & $75.93^{\circ} \mathrm{S}$ & 082120 & 5792-5894 \\
\hline 8001 & $122.14^{\circ} \mathrm{E}$ & $75.58^{\circ} \mathrm{S}$ & 082120 & 6423-6435 \\
\hline 8741 & $130.56^{\circ} \mathrm{E}$ & $74.56^{\circ} \mathrm{S}$ & 082117 & $18930-18942$ \\
\hline 9704 & $154.80^{\circ} \mathrm{E}$ & $73.24^{\circ} \mathrm{S}$ & 082117 & 9297-9468 \\
\hline
\end{tabular}

